\title{
OPTIMISATION OF THE BOMBARDMENT PARAMETERS FOR TRANSFORMATION AND REGENERATION OF STABLE OIL PALM TRANSFORMANTS
}

\section{A RAHMAN NURFAHISZA*; GHULAM KADIR AHMAD PARVEEZ*; OMAR ABDUL RASID* and MAT YUNUS ABDUL MASANI*}

\begin{abstract}
Genetic transformation approaches by using particle bombardment have been an integral part in efforts to improve palm oil quality. The bombardment parameters were previously evaluated to efficiently deliver deoxyribonucleic acid (DNA) during bombardment. However, the evaluation was carried out at transient stage and therefore the results may not be very precise. In order to improve the DNA delivery and regeneration of the oil palm carrying transgenes, a study at stable stage was performed and discussed in this article. Oil palm embryogenic calli were bombarded at several parameters using pAHC25 plasmid. Selection on media containing $1 \mathrm{mg}$ litre $\mathrm{l}^{-1}$ of bialaphos was initiated after one month of bombardment. Then, the concentration of bialaphos was increased to $2 \mathrm{mg} \mathrm{litre}^{-1}$ and subsequently to $3 \mathrm{mg}^{\text {litre }} \mathrm{l}^{-1}$ to effectively eliminate the regeneration of untransformed cells. Generated shoots were subjected to polymerase chain reaction (PCR) analysis. The best bombardment condition was determined based on the highest number of shoots carrying the transgene. The bombardment at 1100 psi helium pressure with $7.5 \mathrm{~cm}$ distance between stopping plate to tissue and one time bombardment using $2.0 \mu \mathrm{g}$ DNA per bombardment was obtained as the best condition for DNA delivery and also minimised tissue damage. Hence, the results of this study will be useful as a guideline to generate transformed oil palm.
\end{abstract}

Keywords: bombardment, oil palm, transformation, bar gene.

Received: 22 November 2019; Accepted: 11 March 2020; Published online: 11 September 2020.

\section{INTRODUCTION}

Oil palm is the most important agricultural crop in Malaysia. Every part of oil palm such as fruits, leaves (Yusof et al., 2016) and trunk (Sulaiman et al., 2012) has their usefulness, which make this plant very valuable agricultural crop for the country. The main product is its oil which is not only useful for food stock but also for non-food applications such as industrial chemicals, pharmaceuticals, and nutraceuticals (Kushairi et al., 2019). However, palm

\footnotetext{
Malaysian Palm Oil Board,

6 Persiaran Institusi, Bandar Baru Bangi,

43000 Kajang, Selangor, Malaysia.

E-mail: fahisza@mpob.gov.my
}

oil needs to compete with other vegetable oils such as rapeseed, sunflower, olive, corn and others. In order to remain competitive, the palm oil industry has to increase its yield as well as to improve the palm oil quality and produce novel products (Kushairi et al., 2018). The conventional method to improve palm oil quality is limited because of long regeneration time, narrow gene pool and open pollination behaviour of oil palm (Parveez et al., 2015b). Thus, another approach, namely genetic engineering was embarked on to introduce specific genes into genomes and speeding up modification process of palm oil quality (Masani et al., 2018).

Various ways to deliver foreign deoxyribonucleic acid (DNA) into the oil palm genome have been 
evaluated such as bombardment (Parveez et al., 2000; 2015a), Agrobacterium-mediated transfer (Izawati et al., 2015; 2012), polyethylene glycol (PEG)mediated transfection and DNA microinjection (Masani et al., 2014). DNA delivery by bombardment has been widely used and proven in many plants such as soyabean (Khalafalla et al., 2005), rice (Tian et al., 2015; Zhao et al., 2011; Higuchi et al., 2001; Datta et al., 2000), wheat (Melchiorre et al., 2002) and banana (Mahdavi et al., 2014; Sreeraman et al., 2005). However, the transformation efficiency of oil palm by bombardment was low at about $1 \%$ $1.5 \%$ (Parveez, 2000). Meanwhile, as reported by Nurfahisza et al. (2014), there were escapes and chimera detected in the regenerated transformed oil palm plantlets. In addition, bombardment method could also result in the integration of multiple copies of transgenes which could subsequently lead to co-suppression (Reddy et al., 2003; El-Shemy et al., 2004).

The physical (Parveez et al., 1997) and biological (Parveez et al., 1998) bombardment parameters affecting DNA delivery in oil palm based on transient expression of gus gene have been evaluated and successfully determined. However, these studies did not show the ability of transformed cells to regenerate which might not be directly translated into stable transformation. Thus, this article evaluates several bombardment parameters to determine the best condition for optimum DNA delivery and subsequently increase the ability to generate oil palm with integrated transgenes. This was basically determined by the presence of transgene into the regenerated shootlets.

\section{MATERIALS AND METHODS}

\section{Plant Materials}

Oil palm embryogenic calli received from the Breeding and Tissue Culture Unit of the Malaysian Palm Oil Board (MPOB) were derived from cabbages. The cabbages were cultured on callus induction media [MS salts (Murashige and Skoog, 1962) $+\mathrm{Y}_{3}$ vitamins (1 g litre $\mathrm{l}^{-1}$ thiamine $\mathrm{HCl}+1 \mathrm{~g}$ litre $^{-1}$ pyridoxine $\mathrm{HCl}+1 \mathrm{~g} \mathrm{litre}^{-1}$ nirotinic acid) (Eeuwans, 1976) $+0.1 \mathrm{~g} \mathrm{litre}^{-1}$ myoinositol and L-glutamine $+3 \%$ sucrose $+5 \mu \mathrm{M}$ 2,4-dichlorophenoxyacetic acid (2, 4-D) + $0.25 \%$ activated charcoal $+0.7 \%$ agar] and incubated in the dark at $28^{\circ} \mathrm{C}$. The calli were subcultured every four weeks (Parveez et al., 2000) until embryogenic calli were formed.

\section{Plasmid Construct and DNA-microcarrier Precipitation}

The bombardment was performed using pAHC25 plasmid which contains gus and bar genes, both driven by maize ubiquitin promoter (Figure 1). The bar gene confers resistance to bialaphos. Precipitation of plasmid DNA onto microcarrier was performed according to the modified method developed by Parveez (1998). While vortexing, $10 \mu \mathrm{l}$ of pAHC25 plasmid DNA $\left(1 \mu \mathrm{g} \mu \mathrm{l}^{-1}\right), 50 \mu \mathrm{l}$ of $\mathrm{CaCl}_{2}(2.5 \mathrm{M})$ and $20 \mu \mathrm{l}$ of spermidine $(0.1 \mathrm{M})$ were sequentially added to the suspension of gold particles $\left(50 \mu \mathrm{l}\right.$ at $\left.60 \mu \mathrm{g} \mathrm{ml}^{-1}\right)$. The mixture was spun for $1 \mathrm{~min}$ at $8000 \mathrm{xg}$ and the supernatant was

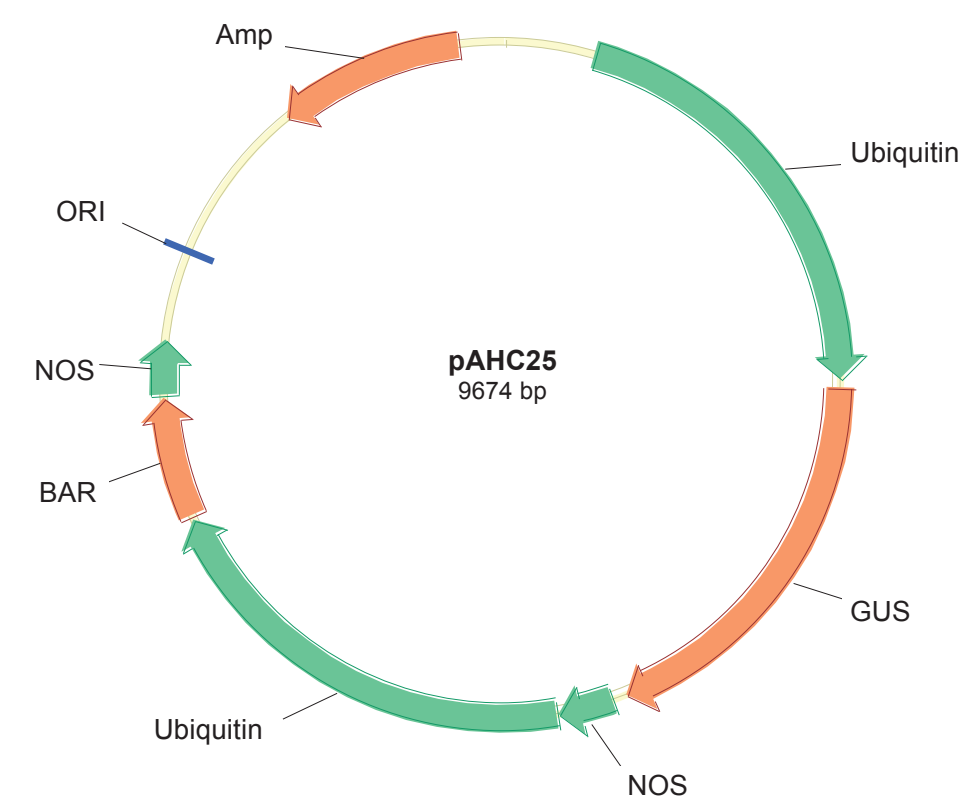

Source: Modified from Christensen and Quail (1996).

Figure 1. Map of pAHC25 plasmid. The plasmid (9674 bp) contains the bar and gus genes under the control of ubiquitin promoter and nos as terminator. The bar gene confers resistance to bialaphos. 
discarded. Then, the mixture was washed using 250 $\mu \mathrm{l}$ of absolute ethanol and spun again at $8000 \mathrm{xg}$ for $40 \mathrm{~s}$. The supernatant was again discarded and the washing step was repeated three times. Finally $60 \mu \mathrm{l}$ of absolute ethanol was added to resuspend the DNA-microcarrier mixture. For bombardment, $7 \mu$ of DNA-microcarrier mixture was loaded onto the centre of macrocarrier and air-dried before bombardment was performed.

\section{Particle Bombardment}

The standard bombardment was performed according to Parveez et al. (1997; 1998). Four parameters (Table 1) were examined independently while the standard conditions (mark with*) were used during the bombardment. The experiment was carried out in five replicates for each treatment.

\section{Selection and Regeneration}

Bombarded calli were cultured on fresh embrogenic calli (EC) agar medium [MS salts (Murashige and Skoog, 1962); Y3 vitamins; 0.0375 $\mathrm{g}_{\text {litre }}^{-1}$ NaFeEDTA; $0.1 \mathrm{~g}_{\text {litre }}{ }^{-1}$ myo-Inositol; $0.1 \mathrm{~g}$ litre $^{-1}$ L-glutamine; 0.1 g litre $^{-1} \mathrm{~L}_{\text {-asparagine; }} 0.1 \mathrm{~g}_{\text {litre }}{ }^{-1}$ L-arginine; 3\% sucrose; $5 \mu \mathrm{M} \alpha$-Naphtaleneacetic acid (NAA); $0.8 \%$ plant agar; $\mathrm{pH}$ 5.7] for about four weeks. The bombarded calli were then transferred onto EC agar media containing $1 \mathrm{mg} \mathrm{litre}^{-1}$ bialaphos followed by $2 \mathrm{mg}$ litre $^{-1}$ and $3 \mathrm{mg} \mathrm{litre}{ }^{-1}$ for the third month and onward.

\section{Molecular Analysis of Putative Transgenic Plantlets}

Leaves from putative transgenic plantlets were cut and subjected to genomic DNA isolation by using the method of Doyle and Doyle (1990) with a modification using $16000 \mathrm{xg}$ of centrifugation speed. The genomic DNA obtained was used as template for PCR analysis by using primers as listed in Table 2. An internal control gene was amplified by using a programme described by Nurfahisza et al. (2014) (data not shown). This is to ensure that the DNA samples were suitable for PCR amplification (Parveez and Majid, 2018). Later, the amplifications of transgenes were carried out by using primers UbibarF1 and BarR2 which would amplify a part of ubiquitin promoter and bar gene. The expected size of the amplified band was $1.2 \mathrm{~kb}$.

The number of shoots so called transformant carrying the bar gene was identified and counted. After that, the number of transformant was divided with five (the number of replicates per treatment) to calculate the average transformant for each treatment. Finally, the value of average transformant obtained for each treatment was plotted into graph.

\section{RESULTS AND DISCUSSION}

Optimising the transformation parameters is one of the crucial studies that needs to be carried out. Parveez et al. $(1997 ; 1998)$ have successfully determined at transient level the optimised parameters for oil palm transformation via particle bombardment by using gus gene. The putative transgenic oil palm plants have been generated by using these optimised parameters. However, analysis on putative transgenic obtained showed that most of the plants were not true transformants (Nurfahisza et al., 2014). This might be due to the expression of transgenes at transient level which

TABLE 1. LIST OF PARTICLE BOMBARDMENT PARAMETERS EVALUATED IN THIS WORK

\begin{tabular}{ll}
\hline Parameters & \multicolumn{1}{c}{ Treatments } \\
\hline Helium pressure $(\mathrm{psi})$ & $650,900,1100^{*}, 1350,1550$ \\
Distance of stopping plate to tissue $(\mathrm{cm})$ & $6.0,7.5^{*}, 9.0,10.5,12.0$ \\
Number of bombardment & $1^{*}, 2^{*}, 3$ \\
DNA quantity $(\mu \mathrm{g})$ & $0.50,1.00,1.25,1.50^{*}, 1.75,2.00$ \\
\hline
\end{tabular}

Note: *Standard condition according to Parveez et al. $(1997 ; 1998)$.

TABLE 2. PRIMERS AND THEIR SEQUENCES USED FOR POLYMERASE CHAIN REACTION (PCR) ANALYSIS

\begin{tabular}{lclc}
\hline Primers & Gene & \multicolumn{1}{c}{ Sequences } & Expected size (kb) \\
\hline Por-12 & Internal & 5'-CCCTCATCCATAGCACA-3' & 1.1 \\
Por-38 & control & 5'-CAGGGAGCAAAGAAGCA-3' & \\
UbiF1 & Bar & 5'-CCGCAGACGGGATCGATTTC-3' & 1.2 \\
BarR2 & & 5'-GTCATGCCAGTTCCCGTGCT-3' & \\
\hline
\end{tabular}

Note: Internal control gene was amplified using Por-12 and Por-38 primers. Transgene was amplified using UbiF1 and BarR2 primers. 
does not reflect the ability of the transformed cells to regenerate. Transient expression can occur whether or not the transgenes integrated into the genome of target tissue. Thus, a few bombardment parameters were evaluated at stable transformation level and discussed in this article. The determination of the most optimum parameters at stable transformation level based on PCR analysis on generated shootlets was much more convincing as it represents the integration of transgene into the plant genome.

\section{Helium Pressure}

A few rupture discs corresponding to different helium pressure were evaluated. After the bombarded calli have been cultured for about 17 months on selection media, a few shoots were obtained (Figure 2). The regenerated shootlets showed normal growth and morphology compared to the wild type. All shoots were subjected to PCR analysis for the identification of the shoots that carry the transgene (data not shown). The highest number of transformants was obtained from calli that were bombarded at 1100 psi helium pressure, followed by 1350 psi, 650 psi and 1550 psi (Figure 3). However, no transformant was obtained from calli that were bombarded at $900 \mathrm{psi}$. The most optimum helium pressure obtained in this study (1100 psi) is similar to the results obtained from the transient study reported by Parveez et al. (1997). The pressure at 1100 psi was not too harsh and could not cause cell injury (Tadesse et al., 2003; Parveez et al., 1997) but strong enough for the microcarrier to penetrate into the targeted tissue (Parveez et al., 1997; Mousavi et al., 2009). Studies on single bud banana (Sreeramanan et al., 2005), male flower of banana (Mahdavi et al., 2014), dates (Mousavi et al., 2009) and sorghum (Tadesse et al., 2003) also found that pressure at 1100 psi was an optimum pressure for bombardment. However, there were also a few bombardments that have been carried out using other pressures such as 650 psi to bombard maize (Frame et al., 2000), 1350 psi for papaya (Che Radziah et al., 2011) and 1800 psi for peanut plant (Schnall and Weissinger, 1995). Nevertheless, too high helium pressure and other harsh bombardment conditions could cause injury to target tissues and subsequently to regeneration of transgenic plants.

\section{Distance from Stopping Plate to Tissue}

In addition to helium pressure, the distance from stopping plate to tissue was also evaluated in this work. The distance was set at five different values, namely $6,7.5,9,10.5$ and $12 \mathrm{~cm}$. The regenerated shoots was subjected to PCR analysis to identify the transformants (Figure 4). The highest number of transformants obtained from calli that were bombarded using $7.5 \mathrm{~cm}$ distance (Figure 5). As for the helium pressure, the result was also similar to the findings reported by Parveez et al. (1997). Study by Ruma et al. (2009) on tomato also showed that $7.5 \mathrm{~cm}$ was the optimum distance for bombardment on shoot tips, hypocotyls and cotyledons of tomato. However, certain studies showed that different distances were more suitable for target tissues of other plants. For example, it was shown that $6 \mathrm{~cm}$ and $9 \mathrm{~cm}$ were the optimum distance for soyabean (Khalafalla et al., 2005) and male flowers of banana (Mahdavi et al., 2014), respectively. The distances from stopping plate to tissue would certainly affect the DNA delivery into the target tissue. The acceleration may be reduced with the distance (Parveez et al., 1997) and this would also reduce the ability of DNA to reach and penetrate the target tissue. Meanwhile, if the distance was too close, the target tissue may be damaged due to the high acceleration of the microcarrier. Thus, distance at $7.5 \mathrm{~cm}$ was the suitable distance at which the DNA could reach the target tissue without causing harmful effects to the tissues.

\section{Number of Bombardment}

The number of bombardment is another parameter that has been shown to affect the transformation efficiency. In this work, the number of bombardment was varied at one, two and three times. Results indicated that only one time bombardment could generate transformed shoots (Figure 6). Although shoots were also generated for two times bombardment but they were not transformants. Meanwhile, no shoot was generated when bombardment was carried out three times. Based on transient study, Parveez et al. (1997) found that one and two times bombardment had no significant effect on the amount of signals obtained. However, there were a number of studies reported two times bombardment gave a better transformation efficiency such as in male flower of banana (Mahdavi et al., 2014), soyabean (Khalafalla et al., 2005), cassava (Zhang et al., 2000) and maize (Petrillo et al., 2008). Two times bombardment may increase the coverage area of target tissues. However, bombardment more than two times might cause mechanical injuries to the tissues (Sreeramanan et al., 2005). The tissue injury could inevitably lead to a low transformation efficiency. For oil palm, one time bombardment was sufficient to deliver DNA into the target tissue and minimise the tissue injury. Meanwhile, multiple bombardment could cause difficulty for tissues to recover and generate into shoots.

\section{DNA Quantity per Bombardment}

The final parameter evaluated in this work was the DNA quantity used in each bombardment. 


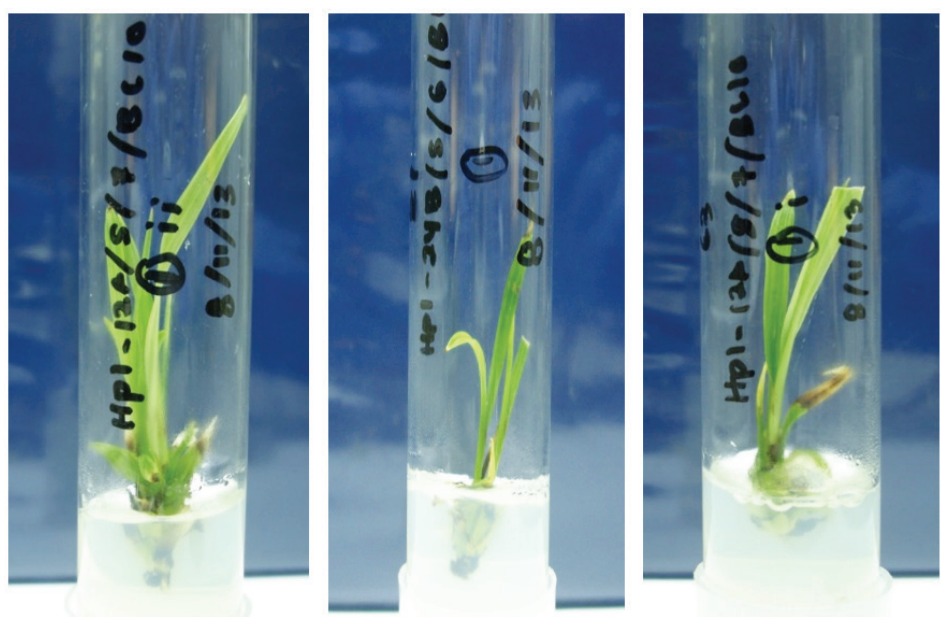

Figure 2. Shootlets generated from calli bombarded with $\mathrm{pAHC} 25$ plasmid after 17 months of selection. Bombarded calli were cultured on embryogenic calli (EC) media containing $1 \mathrm{mg}$ litre ${ }^{-1}$ of bialaphos for a month, followed by culturing at increase bialaphos concentration ( $\left.2 \mathrm{mg}^{\text {litre }} \mathrm{e}^{-1}\right)$ for a month. The calli were then cultured onwards on media with $3 \mathrm{mg}$ litre ${ }^{-1}$ of bialaphos until shootlets generated.

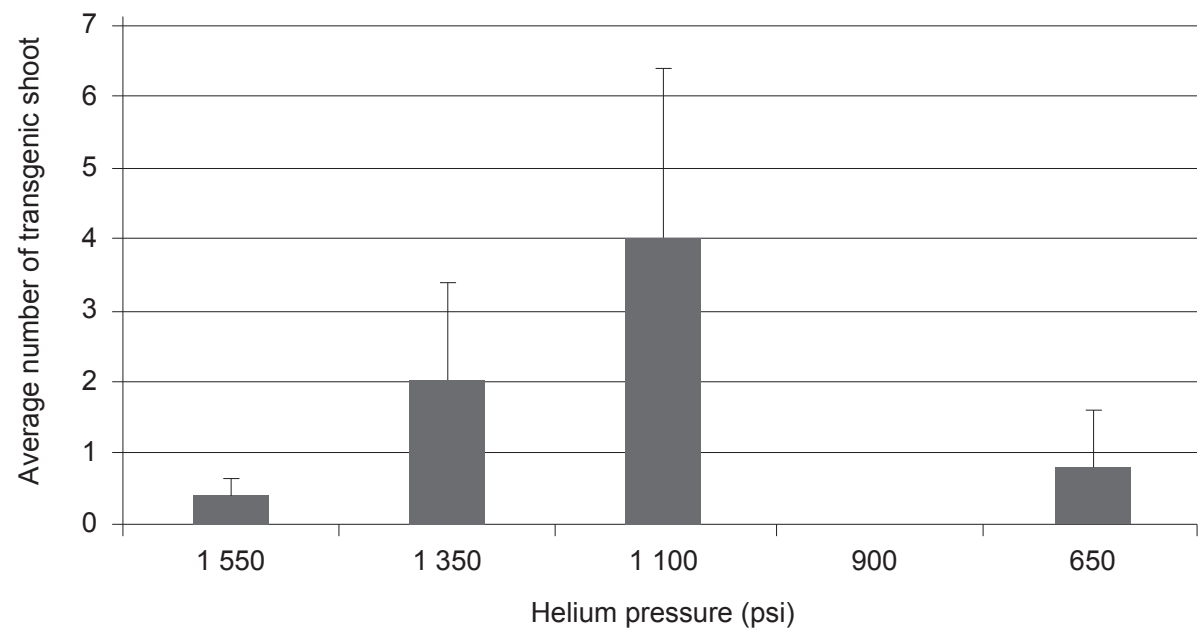

Figure 3. Effects of helium pressure on transformation and regeneration of oil palm transformant. Data presented is the mean of five replicates.

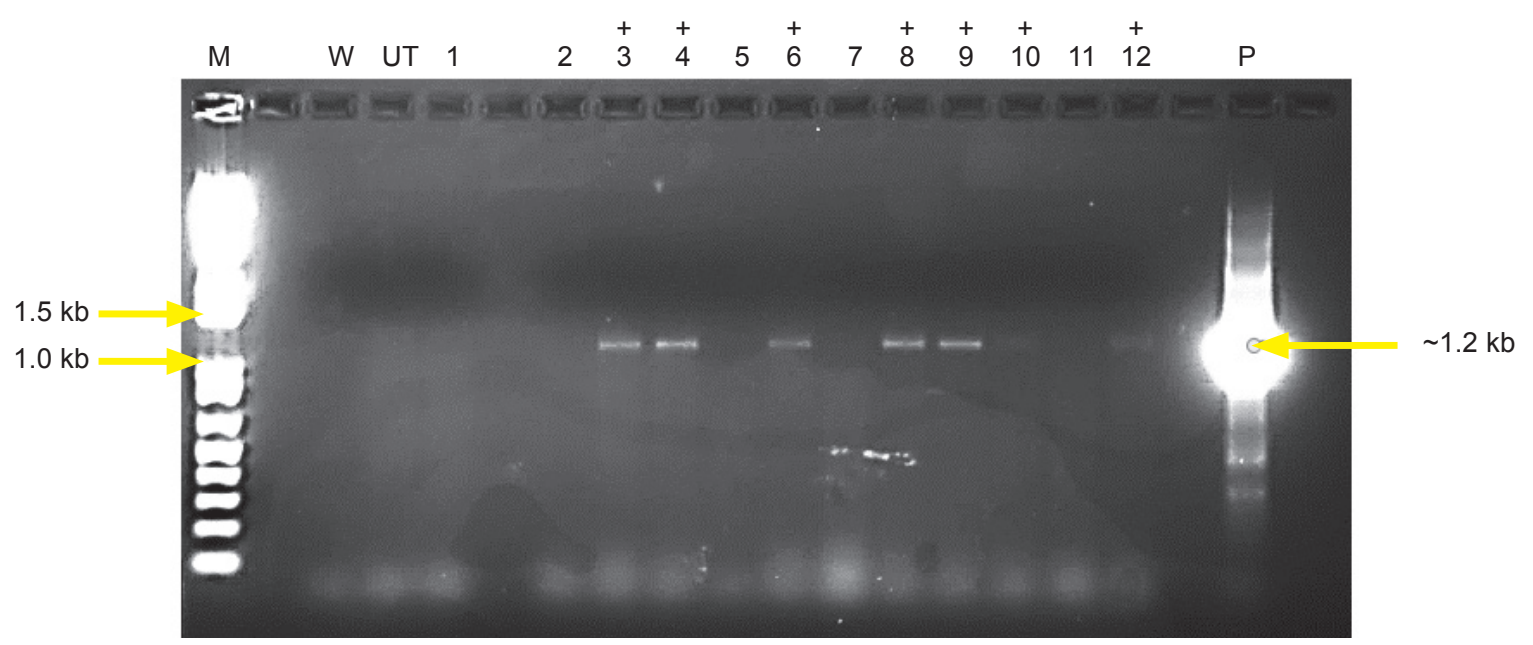

Figure 4. Polymerase chain reaction (PCR) analysis on regenerated shoots to detect the presence of bar gene. Only seven out of 12 regenerated shoots showed the presence of bar gene (amplicon at $1.2 \mathrm{~kb}$ ). Lane $M-1 \mathrm{~kb}$ plus DNA ladder (Invitrogen); $W$ - non-template control (water); UT - untransformed control; 1-12 - regenerated shoots and P - pAHC25 plasmid. 


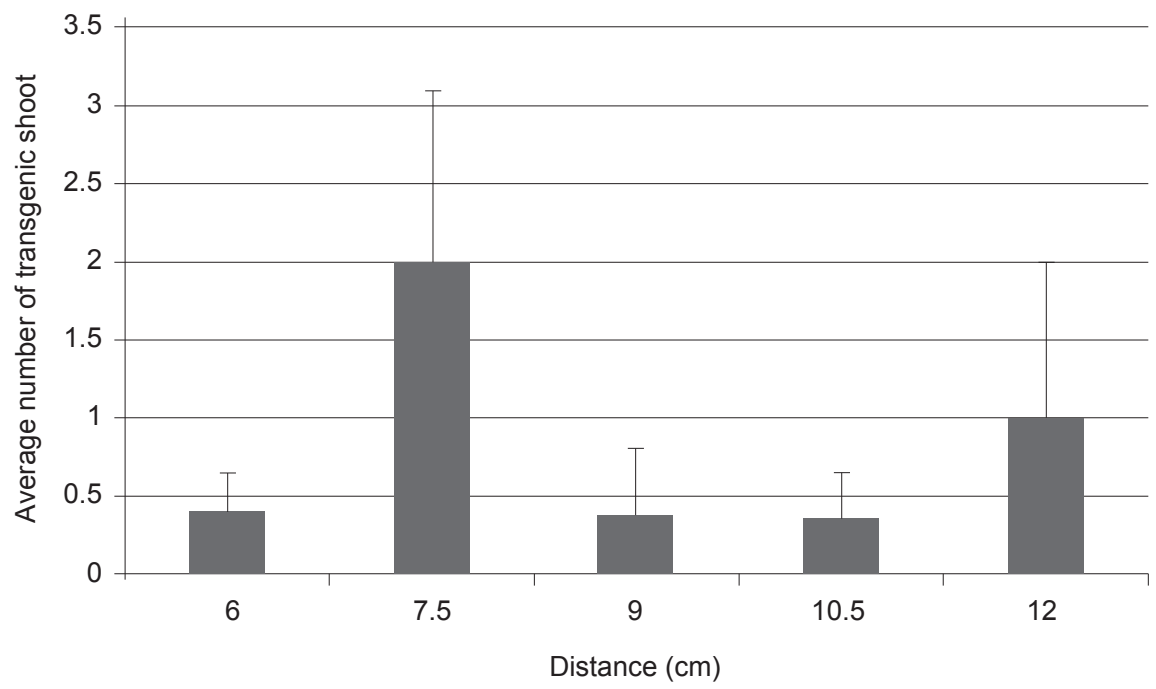

Figure 5. Effects of distance from stopping plate to tissue on transformation and regeneration of oil palm transformant. Data presented is the mean of five replicates.

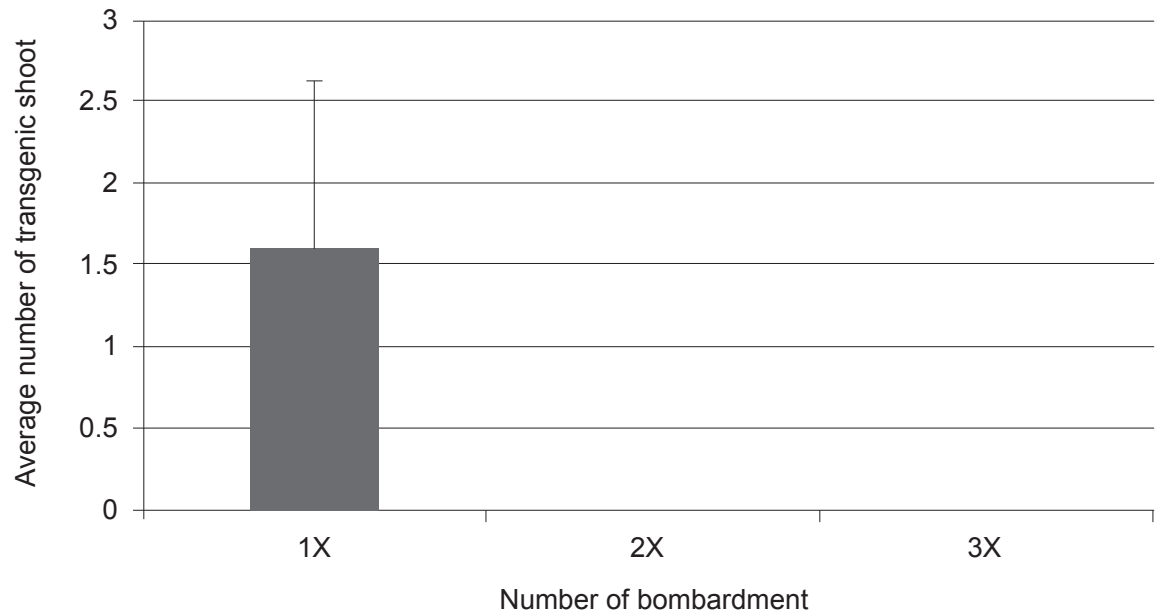

Figure 6. Effects of bombardment number on transformation and regeneration of oil palm transformant. Each value is the means of five replicates.

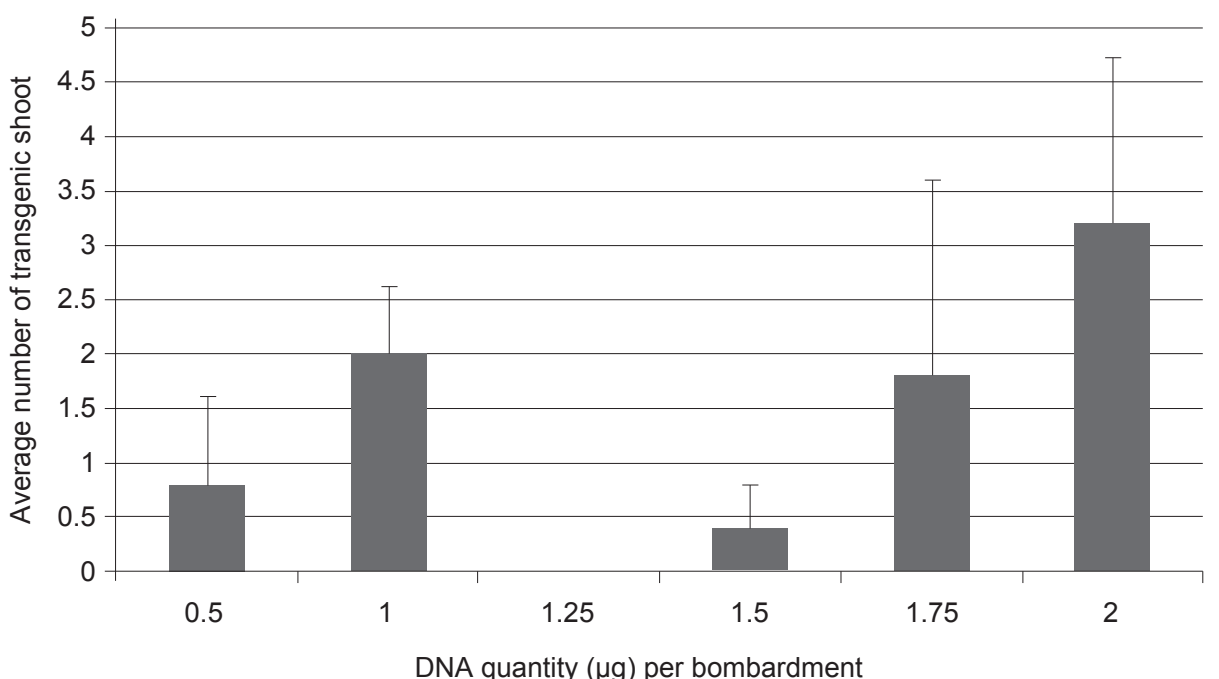

Figure 7. Effects of deoxyribonucleic acid (DNA) quantity per bombardment on transformation and regeneration of oil palm transformant. Each value is the means of five replicates. 
Among five different treatments of DNA quantity per bombardment examined, $2.0 \mu \mathrm{g}$ of DNA per bombardment was shown to produce the highest number of transformants (Figure 7). This result is in contrast to the findings of transient study by Parveez et al. (1998) which indicated that the optimum amount of DNA was at $1.5 \mu \mathrm{g}$. Study on rice (Carsono and Yoshida, 2008) and banana (Sreeramanan et al., 2005; Mahdavi et al., 2014) also used $1.5 \mu \mathrm{g}$ of DNA for optimum bombardment. However, Mousavi et al. (2009) used a much higher DNA quantity per bombardment which was at $2.5 \mu \mathrm{g}$ DNA. A sufficient amount of DNA used in bombardment could increase the transformation efficiency while a low DNA quantity would result in the insufficient ratio of DNA to microcarrier (Matroodi et al., 2013).

\section{CONCLUSION}

The optimisation of biolistic parameters was crucial to increase the transformation efficiency. Numerous optimisation studies on different plants have been carried out as different tissues and plants need different conditions for bombardment. Previous study on oil palm which was based on transient expression showed a slight variation in results as compared to this study which was based on stably transformed shoot generated. Results obtained from this study showed that transformed plantlets were successfully regenerated through one time bombardment with $2.0 \mu \mathrm{g}$ of DNA at pressure of $1100 \mathrm{psi}$ and $7.5 \mathrm{~cm}$ distance between stopping plate to target tissue. The results could be used as a guideline in the effort to generate the stably transformed oil palm.

\section{ACKNOWLEDGEMENT}

The authors would like to thank the management of MPOB for the approval to publish this article. A very special thanks to the staff of Technology Transgenic (TTG) and Clonal Propagation (CPG) Groups of MPOB for their contributions.

\section{REFERENCES}

Carsono, N and Yoshida, T (2008). Transient expression of green fluorescent protein in rice calluses: Optimization of parameters for Helios gene gun device. Plant Prod. Sci., 11(1): 88-95.

Che Radziah, C M V; Nurul Shahnadz, A H; Naziratul Ain, A N and Zainal, Z (2011). Genetic transformation of antisense ACC oxidase in Carica papaya L. CV. Sekaki via particle bombardment. Malays. Appl. Biol., 40(1): 39-45.

Christensen, A H and Quail, P H (1996). Ubiquitin promoter-based vectors for high-level expression of selectable and or screenable marker genes in monocotyledonous plants. Transgenic Res., 5: 213-218.

Datta, K; Koukolíková-Nicola, Z; Baisakh, N; Oliva, N and Datta, S K (2000). Agrobacterium-mediated engineering for sheath blight resistance of indica rice cultivar from different ecosystems. Theor. Appl. Genet., 100: 832-839.

Doyle, J J and Doyle, J L (1990). Isolation of plant DNA from fresh tissue. Focus, 12: 13-15.

El-Shemy, H A; Teraishi, M; Khalafalla, M M; Katsube-Tanaka, T; Utsumi, S and Ishimoto, M (2004). Isolation of soybean plants with stable transgene expression by visual selection based on green fluorescent protein. Mol. Breed., 14: 227-238.

Eeuwans, C J (1976). Mineral requirements for growth and callus initiation of tissue explants excised from mature coconut palms (Cocos nucifera) cultured in vitro. Physiol. Plant, 36: 23-28.

Frame, B R; Zhang, H; Cocciolone, S M; Sidorenko, L V; Dietrich, C R; Pegg, S E; Zhen, S; Schnable, P S and Wang, K (2000). Production of transgenic maize from bombarded type II callus: Effects of gold particle sizes and callus morphology on transformation efficiency. In vitro Cell. Dev. Biol. Plant., 36: 21-29.

Higuchi, K; Watanabe, S; Takahashi, M; Kawasaki, S; Nakanishi, H; Nishizawa, N and Mori, S (2001). Nicotianamine synthase gene expression differs in barley and rice under Fe-deficient conditions. Plant J., 25: 159-167.

Izawati, A M D; Masani, M Y A; Ismanizan, I and Parveez, G K A (2015). Evaluation on the effectiveness of 2-deoxyglucose-6-phosphatephosphatase (DOGR1) gene as a selectable marker for oil palm (Elaeis guineensis Jacq.) embryogenic calli transformation mediated by Agrobacterium tumefaciens. Frontiers in Plant Science, 6 (727): 1-10.

Izawati, A M D; Parveez, G K A and Masani, M Y A (2012). Transformation of oil palm using Agrobacterium tumefaciens. Methods in Molecular Biology, 847: 177-188.

Khalafalla, M M; Rahman, S M; El-Shemy, H; Nakamoto, Y; Wakasa, K and Ishimoto, M (2005). Optimization of particle bombardment condition by monitoring of transient sGFP(S65T) expression in transformed soybean. Breeding Science, 55: 257-263. 
Kushairi, A; Loh, S K; Azman, I; Hishamuddin, E; Ong-Abdullah, M; Izuddin, Z B M N; Razmah, G; Sundram, S and Parveez, G K A (2018). Oil palm economic performance in Malaysia and $R \& D$ progress in 2017. J. Oil Palm Res. Vol. 30(2): 163 $-195$.

Kushairi, A; Ong-Abdullah, M; Nambiappan, B; Hishamuddin, E; Izuddin, Z B M N; Razmah, G; Subramaniam, V; Sundram, S and Parveez, G K A (2019). Oil palm economic performance in Malaysia and R\&D progress in 2018. J. Oil Palm Res. Vol. 31(2): 165-194.

Mahdavi, F; Mahmood, M and Noor, N M (2014). Optimization of particle bombardment parameters for DNA delivery into the male flowers of banana. Biologia. Section Cellular and Molecular Biology, 69(7): 888-894. DOI: 10.2478/ s11756-014-0391-7.

Masani, M Y A; Izawati, A M D; Rasid, O A and Parveez, G K A (2018). Biotechnology of oil palm: Current status of oil palm genetic transformation. Biocatal. Agric. Biotechnol., 15: 335-347.

Masani, M Y A; Noll, G; Parveez, G K A; Sambanthamurthi, R and Pruefer, D (2014). Efficient transformation of oil palm protoplasts by PEGmediated transfection and DNA microinjection. PLOS ONE, 9(5): e96831. DOI: 10.1371/ journal. Pone.0096831.

Matroodi, S; Motallebi, M; Zamani, M; Mousavi, A; Davoodi, D and Moghaddassi-Jahromi, Z (2013). Sugarcane (NCo310) transient transformation using uidA reporter gene. Iran J. Biotech., 11(2): 8995.

Melchiorre, MN; Lascano, H R and Trippi, VS (2002). Transgenic wheat plants resistant to herbicide Basta obtained by microprojectile bombardment. Biocell., 26: 217-223.

Mousavi, M; Mousavi, A; Habashi, A A and Arzani, K (2009). Optimization of physical and biological parameters for transient expression of uidA gene in embryogenic callus of date palm (Phoenix dactylifera L.) via particle bombardment. African J. Biotechnology, 8(16): 3721-3730.

Murashige, T and Skoog, F (1962). A revised medium for rapid growth and bio assays with tobacco tissue cultures. Physiol. Plant., 15: 473-497.

Nurfahisza, A R; Rafiqah, M A; Masani, M Y A; Nor Hanin, A A; Rasid, O A and Parveez, G K A (2014). Molecular analysis of transgenic oil palm to detect the presence of transgenes. J. Oil Palm Res. Vol. 26: 73-80.
Parveez, G K A (2000). Production of transgenic oil palm (Elaeis guineensis Jacq.) using biolistic techniques. Molecular Biology of Woody Plants (Jain, S M and Minocha, S C eds.). Kluwer Academic Publishers. p. 327-350.

Parveez, G K A (1998). Optimization of Parameters Involved in the Transformation of Oil Palm Using the Biolistic Method. Ph.D thesis. Universiti Putra Malaysia. $254 \mathrm{pp}$.

Parveez, G K A and Majid, N A (2018). Green fluorescent protein as a visual selection marker for oil palm transformation. Industrial Crops and Products., 115: 134-145.

Parveez, G K A; Bahariah, B; Ayub, N H; Masani, M Y A; Rasid, O A; Tarmizi, A H and Ishak, Z (2015a). Production of polyhydroxybutyrate in oil palm (Elaeis guineensis Jacq.) mediated by microprojectile bombardment of PHB biosynthesis genes into embryogenic calli. Front. Plant Sci., 6: 598.

Parveez, G K A; Rasid, O A; Masani, M Y A and Sambanthamurthi, R (2015b). Biotechnology of oil palm: Strategies towards manipulation of lipid content and composition. Plant Cell Report, 34: 533-543.

Parveez, G K A; Rasid O A; Zainal, A; Masri, M M; Majid, N A; Fadillah, H H; Yunus, A M M and Cheah, S C (2000). Transgenic oil palm: Production and projection. Biochem. Soc. Trans., 28: 969-972.

Parveez, G K A; Chowdhury, M K U and Saleh, N M (1998). Biological parameters affecting transient GUS gene expression in oil palm (Elaeis guineensis Jacq.) embryogenic calli via microprojectile bombardment. Industrial Crops and Products, 8: 17-27.

Parveez, G K A; Chowdhury, M K U and Saleh, N $M$ (1997). Physical parameters affecting transient GUS gene expression in oil palm (Elaeis guineensis Jacq.) using the biolistic device. Industrial Crops and Products, 6: 41-50.

Petrillo, C P; Carneiro, N P; Purcino, A A C; Carvalho, C H S; Alves, J D and Carneiro, A A (2008). Optimization of particle bombardment for the genetic transformation of Brazillian maize inbred lines. Pesquisa Agropecuaria Brasileira, 43: 371-378.

Reddy, M S; Dinkins, R D and Collins, G B (2003). Gene silencing in transgenic soybean plants transformed via particle bombardment. Plant Cell Report, 21: 676-683.

Ruma, D; Dhaliwal, M S; Kaur, A and Gosal, S S (2009). Transformation of tomato using biolistic 
gun for transient expression of the $\beta$-glucuronidase gene. Indian J. Biotechnology, 8: 363-369.

Schnall, J A and Weissinger, A K (1995). Genetic transformation in Arachis hypogaea L. (peanut). Biotechnology in Agriculture and Forestry (Bajaj, Y P S ed.). Springer, India. p. 135-144.

Sreeramanan, S; Maziah; Abdullah, M P; Sariah, M; Xavier, R and Nor' Aini, M F (2005). Physical and biological parameters affecting transient GUS and GFP expression in banana via particle bombardment. Asia Pacific J. Molecular Biology and Biotechnology, 13(1): 35-57.

Sulaiman, O; Salim, N; Nordin, N A; Hashim, R; Ibrahim, M and Sato, M (2012). The potential of oil palm trunk biomass as an alternative source for compressed wood. Bioresources, 7(2): 2688-2706.

Tadesse, Y; Sagi, I; Swennen, R and Michel, J (2003). Optimisation of transformation conditions and production of transgenic sorghum (Sorghum bicolor) via microprojectile bombardment. Plant Cell, Tiss. Org. Cult., 75: 1-18.

Tian, X; Hao, J; Fang, B; Geng, P; La, H; Huang, D and Wang, $H$ (2015). Transformation of upland rice with the bar gene and selection for resistance to the herbicide Basta. Euphytica, 205: 151-167.

Yusof, N Z; Gani, S S A; Siddiqui, Y; Mokhtar, N F M and Hassan, Z A A (2016). Potential uses of oil palm (Elaeis guineensis) leaf extract in topical application. J. Oil Palm Res. Vol. 28(4): 520-530.

Zhang, P; Legris, G; Coulin, P and Puonti-Kaerlas, J (2000). Production of stably transformed cassava plants via particle bombardment. Plant Cell Report, 19: 939-945.

Zhao, Y; Guo, L; Wang, H and Huang, D (2011). Integration and expression stability of transgenes in hybriding transmission of transgenic rice plants produced by particle bombardment. Mol. Plant Breed., 2: 48-59. 